\title{
The Role of the Academic Supervision of School Heads in Improving Teacher Performance in the Pandemic Time
}

\author{
Sri Prihatin ${ }^{1 *}$, Happy Fitria ${ }^{2}$, Yessi Fitriani ${ }^{2}$ \\ ${ }^{l}$ SD Negeri $35 \mathrm{OKU}$, \\ ${ }^{2}$ Universitas PGRI Palembang \\ *Corresponding Author. Email: prihatinsri15@gmail.com
}

\begin{abstract}
The adaptation of distance learning that forces the world of education in the context of serving the right to a proper education for students, continues to be cultivated and developed. Improved teacher performance in implementing pandemic learning can be improved through academic supervision by the principal. This study aims to determine the role of principal academic supervision in improving teacher performance during a pandemic. The research method used is a qualitative method with a descriptive approach. Data collection techniques through interviews, observation and documentation review. The results of the study can be concluded that the academic supervision of school principals has a very important role in improving teacher performance during the pandemic. The data obtained from the principal's academic supervision is categorized as good while the teacher's performance is categorized as good. The results of the supervision of the principal are proportional to the performance of the teacher, this shows that the supervision of the principal is very important in improving teacher performance.
\end{abstract}

Keywords: Academic Supervision, Principal, Teacher Performance.

\section{INTRODUCTION}

The pandemic Covid 19has succeeded in changing the way learning is implemented in Indonesia. From the tertiary level, high school, junior high school, elementary school and even Paud level. Education minister Nadiem Makarin's decision on distance learning said that adjusting online learning is still difficult, at least there is still learning rather than no learning Ridho [1]

Several regional heads such as DKI, West Java, Yogyakarta and Central Java decided to postpone face-to-face learning in order to prioritize the safety of students and educational staff Himawan [2]. Likewise, the South Sumatra regional government in circular No: 420/12553 / Disdik.SS / 2020 concerning the implementation of learning in the even semester of the 2020/2021 school year during the pandemic Covid 19.

This is a challenge for the world of education, both in the transformation of knowledge and skills in the use of technology to make skilled learners in the 21 st century, namely self-directed learning which is the outcome of education. As an adjustment to keep learning how to deal with the problems caused by the Covid 19 pandemic, including the implementation of technical measures, reconstruction of the system and the revitalization [3]

In the pandemic situation covid 19 in several elementary schools there are still many obstacles in the implementation of learning. This requires collaboration between schools, in this case the principal and teachers, with students and parents [4]. There are still teachers who are technologically illiterate and the lack of variety in learning methods requires guidance, guidance and efforts from the principal through supervision. Supervision is the process, guidance, guidance and efforts of the principal to the teacher to improve the learning situation in order to achieve the goals of Pidarta; Suryosubroto [5]; Daryanto and Rahmawati [6]

The opinion of Alfonso, Fith and Neville in Rodliyah [7] that good academic supervision is supervision that is able to function to achieve multiple goals, namely a) professional development b) motivation growth c) quality control. It is hoped that the change in teacher behavior towards a higher quality will lead to better learning behavior of students.

The research objective was to determine the role of principal academic supervision in improving 
teacher performance during a pandemic. Since the outbreak of the corona 19 virus, problems have arisen in the world of education. Several regulations aimed at breaking the covid chain greatly affect the implementation of learning [8]. To overcome this, it requires leaders in schools, namely school principals who function as leaders, managers, educators, supervisors, administrators, motivators and innovators Djafri [9]; Andang [10]; Fitria et al. [11]

Regarding the principal's function as a supervisor, competencies that must be possessed include planning academic supervision programs, implementing academic supervision of teachers and following up on the results of academic supervision in order to improve teacher performance Sohiron [12]

In order to improve teacher supervision and control to improve the performance of school principals as supervisors, they must master the school curriculum, in order to provide coaching, guidance and input in improving learning Hendarman and Rohanim [13]; Fitria [14], Fitia et al [15]. The duty of the principal in supervision is to provide guidance, assistance, supervision and assessment in the implementation and development of learning Kristiawan et al. [16]. Ahmad [17] argued that in addition to carrying out his obligations as educators, administrators and creators of the work climate, school principals have duties and responsibilities towards superiors, subordinates and the work environment.

In a period of distance learning due to the pandemic, the presence of teachers remains irreplaceable. The teacher is a teacher and educator in schools who form students to have better character, knowledge and skills in applying [19]. Teacher performance is the level of success of teachers in carrying out tasks in accordance with their responsibilities and authorities based on performance standards to achieve goals. Teacher competence in the learning process and outcomes is grouped into four abilities, namely planning teaching and learning programs, implementing / managing the teaching and learning process, assessing the teaching and learning process and mastering [20]. Sudjana's teaching materials. New habits in the context of preventing Covid 19 include maintaining distance and avoiding crowds, making learning experience another adaptation to previous habits. Implementation of learning is not allowed face-to-face, so distance learning is carried out. Can be reached by learning outside the network (offline) and learning online (online). For offline learning, it can be reached through students taking learning materials / assignments at school in turns, or with visiting teachers [21]. This is done because of the limited facilities and infrastructure for implementing online learning, cause the facility in educational management was essential [30]. For example, the unavailability of android, data packet or signal is the main problem. Besides that, human resources are also in mastery of IT. Opinion of Dirman and Cicih Juarsih the competence and performance of teachers in implementing learning must have knowledge of: planning, implementation and assessment of learning; effective learning; effective learning communication, scientific and contextual learning; learning strategies and methods; attention and motivation of students, effective classroom management; use of various subject matter; use of multiple media sources and use of IT tools. According to Tabrani in Pianda [22] suggests that the success of teacher performance is influenced by several factors, namely work motivation, work ethic, work environment, duties and responsibilities and performance optimization. There are seven basic teaching skills that a teacher must have, namely 1) questioning skills 2) reinforcement skills 3) variation skills 4) explaining skills 5) opening and closing lessons 6) discussion guiding skills 7) class management skills. However, during the pandemic, the skills of a teacher increase in the use of learning methods. Meanwhile, Jelantik [23] argues that the factors that influence teacher performance are motivation, appreciation and work environment. Teacher performance is influenced by internal factors, namely factors that come from the teacher and external factors, namely factors that come from outside the teacher.

Some of the problems that occur today, the average primary school teacher has difficulty learning online. One of the reasons is the lack of knowledge of information technology. To respond to this, some teachers are learning to master information technology independently or collectively, taking part in webinars, and attending KKG activities in the context of adapting learning during the pandemic. In addition, in order to improve teacher performance, maximum supervision is needed, as assistance and guidance by the principal aimed at improving teacher performance.

\section{METHODS}

The research location was at SD Negeri 35 OKU, Lubuk Raja district. With 8 respondents consisting of the principal, 6 classroom teachers and 1 sports teacher. The research method used in this research is a qualitative method. According to Sugiyono [24] qualitative method is a research method used to examine the condition of a natural object, where the researcher is the key instrument, the data collection technique is done by triangulation, so that both data and data analysis are qualitative. Qualitative research aims to understand a condition 
with a detailed and in-depth description of a natural setting, about what happens according to what it is in the field [25]. Researchers describe research activities carried out on certain objects in a clear and systematic manner, with the aim of explaining and predicting a symptom based on data obtained in Sukardi's field [26]. The approach used in this study is a qualitative descriptive approach which is used to determine the role of academic supervision by the principal on the learning process carried out by teachers of SD Negeri 35 OKU. In this study, the researcher compared the principal's academic supervision data consisting of planning, implementation, evaluation and supervision with teacher performance appraisal data which included pedagogical, personality, social and professional data.

Data collection techniques are a way to obtain research data. Siyoto and Sodik [27] stated that data collection activities could be carried out through a questionnaire, interview methods, and documentation methods. Qualitative data collection, according to Lincoln and Guba, as quoted by Salim and Syahrum [28] uses methods of collecting data through interviews, observations and documents that support and complement each other in fulfilling the data. The data collection techniques in this study were 1) interviews, namely direct interviews with respondents which aimed to determine academic supervision activities and teacher learning activities at SD Negeri $35 \mathrm{OKU}$; 2) observation, namely direct observation in the place and the object being observed, namely the academic supervision activities carried out by the principal and the improvement of teacher performance at SD Negeri 35 OKU; 3) documentation, in the form of physical data such as documentation of the results of the principal's academic supervision in the form of assessments based on supervision instruments. Principal supervision instruments cover aspects of planning, implementation, evaluation and supervision, while teacher performance instruments cover pedagogical, personal, social and professional aspects.

Data analysis is the process of finding and compiling the results of interviews, field notes and documentation by organizing data into categories, describing, synthesizing, compiling and selecting then making conclusions so that they are easily understood by oneself and others. Data analysis techniques include data reduction, data presentation and drawing conclusions. The data obtained will be processed using qualitative research, then domain analysis is carried out to obtain a picture through the process of data reduction, display and verification. As a guideline for determining the criteria for the achievement category according to the Director
General of GTK, Ministry of Education and Culture [29].

Table 1. Criteria for Category Achievement Category

\begin{tabular}{|l|}
\hline Classification Range Percentage \\
\hline A Very Good $86 \%-100 \%$ \\
B Good $76 \%-85 \%$ \\
C Enough $56 \%-75 \%$ \\
D Less Below $55 \%$ \\
\hline
\end{tabular}

\section{RESULTS AND DISCUSSION}

\section{The Role of Principal Academic Supervision}

To be able to find out the role of supervision, researchers conducted academic supervision observations made by the principal with aspects of planning, implementation, evaluation and supervision.

1. Planning

Table 2. Supervision planning instrument

\begin{tabular}{|c|c|c|c|c|}
\hline \multirow{2}{*}{ Indicator } & \multicolumn{4}{|c|}{ Score } \\
\hline & 1 & 2 & 3 & 4 \\
\hline a. Tells the teacher & & & & \\
\hline b. Prepare a supervision program & & & & \\
\hline c. Prepare the instrument & & & & \\
\hline 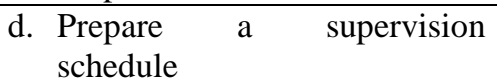 & & & & \\
\hline $\begin{array}{l}\text { e. Agreement on the object being } \\
\text { supervised }\end{array}$ & & & & \\
\hline f. Study the lesson plan & & & & \\
\hline
\end{tabular}

Guidelines for filling (4) the principal implements all the criteria in the indicator: very good (3) the principal the school implements most of the criteria: good (2) the principal implements a small number of criteria: sufficient / sometimes (1) the principal does not fulfill all of the criteria: less / no

From the interview activities and the results of observations in the field aspects of supervision planning carried out by the elementary school principal Negeri 35 OKU based on the guidelines for filling out the planning aspects of observation are (a) the principal notifies the staff of teachers about the holding of supervision (b) the principal makes a supervision program. (c) The principal prepares a supervision instrument. (d) The principal makes a schedule of supervision (e) The principal makes an agreement about the object of supervision (f) The principal studies the teacher's lesson plan

In the aspect of planning the supervision carried out by the principal reaches $83.3 \%$ is included in the B classification good category 


\section{Implementation}

In the aspect of implementing the supervision of the principal, there are indicators in the following instruments

Table 3. Instrument for Implementing Supervision

\begin{tabular}{|c|c|c|c|c|}
\hline \multirow{2}{*}{ Indicators } & \multicolumn{4}{|c|}{ Score } \\
\hline & 1 & 2 & 3 & 4 \\
\hline a. Giving greetings & & & & \\
\hline $\begin{array}{l}\text { b. Sitting in an inconspicuous } \\
\text { place }\end{array}$ & & & & \\
\hline $\begin{array}{l}\text { c. Not reprimanding the teacher's } \\
\text { mistakes }\end{array}$ & & & & \\
\hline d. Record every activity & & & & \\
\hline e. Using electronic tools & & & & \\
\hline $\begin{array}{l}\text { f. Prepare entries in the form of a } \\
\text { checklist }\end{array}$ & & & & \\
\hline $\begin{array}{l}\text { g. Paying attention to learning } \\
\text { conditions }\end{array}$ & & & & \\
\hline
\end{tabular}

Guidelines filling in (4) the principal implements all the criteria in the indicators: very good (3) the principal implements most of the criteria: good (2) the principal implements a small number of criteria: sufficient / sometimes (1) the principal does not fulfill all of the criteria: lacking / not

Indicators for the implementation aspect are (a) Kepa The school greets the teacher (b) The principal looks for an inconspicuous seat (c) The principal does not reprimand the teacher for mistakes during learning (d) The principal records every activity (e) The principal uses electronic equipment (f) The principal prepares filling in the form of a checklist $(g)$ The principal pays attention to the learning conditions. for the implementation of the supervision of the principal of SD Negeri 35 OKU, it reached $85.7 \%$, which was classified as B category with good category. In the implementation aspect, most of the indicators have been met with a maximum value of four points, but there are still weaknesses in point e, namely the use of electronic devices in carrying out supervision.

\section{Evaluation}

The evaluation activity of the instrument used is

Table 4. Evaluation instruments for supervision

\begin{tabular}{|c|c|c|c|c|}
\hline \multirow{2}{*}{ Indicators } & \multicolumn{4}{|c|}{ Score } \\
\hline & 1 & 2 & 3 & 4 \\
\hline $\begin{array}{l}\text { a. Discussing the results of } \\
\text { supervision }\end{array}$ & & & & \\
\hline b. Prepare for evaluation & & & & \\
\hline $\begin{array}{l}\text { c. Planning a place for } \\
\text { conversation }\end{array}$ & & & & \\
\hline d. Planning a conversation time & & & & \\
\hline $\begin{array}{l}\text { e. Being friendly does not } \\
\text { monopolize }\end{array}$ & & & & \\
\hline $\begin{array}{l}\text { f. conversation Conversations } \\
\text { according to observational data }\end{array}$ & & & & \\
\hline g. Give an opportunity to argue & & & & \\
\hline h. Explain teacher weaknesses & & & & \\
\hline $\begin{array}{l}\text { i. Give suggestions for } \\
\text { improvement }\end{array}$ & & & & \\
\hline j. Documenting results discussion & & & & \\
\hline
\end{tabular}

Guidelines for filling in (4) the principal implements all the criteria in the indicators: very good (3) the principal implements most of the criteria: good (2) the principal implements a small number of criteria: sufficient / sometimes (1) the principal does not do everything criteria: less / not

Based on the data in the field, the researcher managed to collect data according to the guidelines for filling out the observation aspects of the evaluation as follows (a) The principal discusses the results of supervision (b) The principal prepares the evaluation (c) The principal determines the place of conversation (d) The principal $\mathrm{m}$ Determining the timing of the conversation (e) The principal is friendly, does not buy up conversations (f) the conversation does not come out of the observation data ( $\mathrm{g}$ ) the teacher is given the opportunity to dialogue and expresses an opinion (h) the principal explains the weakness to be used as motivation for improvement ( i) suggestions for easy and practical deberi improvement (j) the results of the conversation are documented according to each teacher who has been supervised.

Based on data from the field, it shows that supervision activities from the evaluation aspect achieved an achievement of $82.5 \%$ classified B with the good category. At point $\mathrm{f}$, attention needs to be paid, namely the conversation out of observation data to overcome this, the principal needs to make data records in accordance with the guidance to be delivered. 


\section{Supervision}

Supervision is a part of supervision activities to supervise the results of planning, implementation and evaluation in order to achieve goals. The instrument for knowing the supervision of supervision is

Table 5. Instruments for Supervision of Supervision

\begin{tabular}{|c|c|c|c|c|}
\hline \multirow{2}{*}{ Indicators } & \multicolumn{4}{|c|}{ Score } \\
\hline & 1 & 2 & & 4 \\
\hline $\begin{array}{l}\text { a. Documents of teachers who } \\
\text { are supervised }\end{array}$ & & & & \\
\hline $\begin{array}{l}\text { b. Documents according to the } \\
\text { object of supervision }\end{array}$ & & & & \\
\hline c. Provide feedback & & & & \\
\hline d. Determine learning monitoring & & & & \\
\hline $\begin{array}{l}\text { e. reports on learning progress } \\
\text { learning }\end{array}$ & & & & \\
\hline 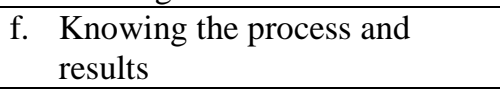 & & & & \\
\hline g. Assessing learning outcomes & & & & \\
\hline $\begin{array}{l}\text { h. Knowing the quality standards } \\
\text { of learning outcomes }\end{array}$ & & & & \\
\hline $\begin{array}{l}\text { i. Developing the profession } \\
\text { teacher }\end{array}$ & & & & \\
\hline $\begin{array}{ll}\text { j. } & \text { Procurement and utilization of } \\
\text { bljr sources }\end{array}$ & & & & \\
\hline
\end{tabular}

Guidelines for filling (4) the principal implements all the criteria in the indicators: very good (3) the principal implements most of the criteria: good (2) the principal implements a small number of criteria: sufficient / sometimes (1) The principal does not perform all the criteria: lacking / not

In the supervision aspect of the principal of SD Negeri 35 OKU reaching $82.5 \%$ is classified B with a good category

In the aspect of supervision there are indicators (a) the principal has a teacher data document that has been supervised (b) Custom document contents, starting date, the purpose of the data obtained, record discussions, problem solving and suggestions (c) the principal provides feedback to teachers who are experiencing difficulties (d) The principal determines the monitoring of the implementation of teaching and learning activities (e) The principal asks for a report on learning progress after evaluation supervision. (f) The principal is aware of the learning process and results (there are documents of learning tools such as syllabus, lesson plans, learning media, etc.) (g) The principal assesses the learning outcomes (there is an assessment sheet that has been filled in after supervision) (h) The principal knows the quality standard of student learning outcomes. (i) The principal is able to develop the teaching profession. (j) The principal is to procure and utilize learning resources.

Based on data from the aspects of the principal's academic supervision, it was found that the supervision plan reached $83.3 \%$, implementation reached $85.7 \%$, evaluation was $82.2 \%$ and supervision was $82.2 \%$ so that the average academic supervision of the principal of SD Negeri 35 OKU reached $83.35 \%$

\section{Teacher Performance Assessment.}

To find out the performance of teachers at SD Negeri 35 OKU, the principal supervises the academy with pedagogical, personality, social and professional aspects.

1. Pedagogical Aspects

Pedagogical competence is the teacher's ability to manage learning. To get information about the pedagogical competence of the researcher, the researcher prepared the following instruments

Table 6. Teacher's Pedagogical Instruments

\begin{tabular}{|l|l|l|l|l|}
\hline \multirow{2}{*}{ Indicator } & \multicolumn{3}{|c|}{ Score } \\
\cline { 2 - 5 } & 1 & 2 & 3 & 4 \\
\hline a. $\begin{array}{l}\text { Understand the educational } \\
\text { foundation }\end{array}$ & & & & \\
\hline b. Understand students & & & & \\
\hline c. Develop curriculum / syllabus & & & & \\
\hline d. Learning design & & & & \\
\hline e. Dialogical implementation of & & & & \\
\hline f. $\begin{array}{l}\text { technology Utilization of } \\
\text { technology }\end{array}$ & & & & \\
\hline g. $\begin{array}{l}\text { Evaluation of learning } \\
\text { outcomes }\end{array}$ & & & & \\
\hline h. Development of student \\
potential
\end{tabular}

Guidelines for filling (4) the principal implements all the criteria in the indicators: very good (3) the principal implements most of the criteria: good (2) the principal implements a small number of criteria: sufficient / sometimes (1) the principal does not fulfill all the criteria: less / no

In the pedagogical aspect, there are indicators (a) the teacher understands the insight / foundation of education (b) the understanding of students. (c) curriculum/syllabus development (d) Learning design (e) Dialogic learning (f) Utilization of learning technology (g) Evaluation of learning outcomes (h) Development of students to actualize their various potentials.

Based on the results of research observations, $83.5 \%$ of the pedagogical aspects of the teacher were included in the B classification with the good 
category. Most of the indicators of pedagogical aspects of SD Negeri 35 OKU teachers have been fulfilled. The weakness occurs in point c, namely curriculum / syllabus development. This problem occurs due to restrictions on learning. The distance learning system that is full of rigor makes teachers at SD Negeri 35 experiencing difficulties in curriculum development. Simplification of the curriculum is recommended and more appropriate in times of pandemic, this can help students who experience psychological stress during distance learning. To overcome the shortcomings in points $f$ namely the use of technology to vary the method is the method of teachergo

2. Personality aspect

Teachers' competence further is their personality. The instrument for teacher personality aspects that the researchers have prepared is

Table 7. Teacher Personality Instruments

\begin{tabular}{|l|l|l|l|l|}
\hline \multirow{2}{*}{ Indicator } & \multicolumn{3}{|c|}{ Score } \\
\hline & 1 & 2 & 3 & 4 \\
\hline a. Attitude of faith and piety & & & & \\
\hline b. Attitude of noble character & & & & \\
\hline c. Wise and wise & & & & \\
\hline d. attitude Democratic & & & & \\
\hline e. attitude Independent & & & & \\
\hline f. attitude An authoritative & & & & \\
\hline g. attitude Stable & & & & \\
\hline h. attitude Adult & & & & \\
\hline i. attitude Honest & & & & \\
\hline j. attitude Sportsmanship & & & & \\
\hline k. Be a role model for participants & & & & \\
& students & & & \\
\hline $\begin{array}{l}\text { l. Evaluate their own } \\
\text { performance Self- }\end{array}$ & & & & \\
\hline m. development independently & & & & \\
\hline
\end{tabular}

Guidelines for filling in (4) the principal implements all the criteria in the indicators: very good (3) the principal implements most of the criteria: good (2) the principal implements a small number of criteria: sufficient / sometimes (1) the principal did not fulfill all the criteria: lacking / no

Personality data that were successfully collected by researchers through the guidelines for filling out teacher performance observations were indicators (a) the teacher showed an attitude of faith and piety (b) the teacher showed a noble attitude (c) the teacher showed wise and wise attitude (d) the teacher shows a democratic attitude (e) the teacher shows $\mathrm{n}$ independent attitude ( $\mathrm{f}$ ) the teacher shows an authoritative attitude ( $\mathrm{g}$ ) the teacher shows a stable attitude (h) the teacher shows an adult attitude (i) the teacher shows an honest attitude (j) the teacher shows a sportsmanship attitude $(\mathrm{k})$ the teacher is a role model for students (l) teachers objectively evaluate their own performance (m) teachers develop themselves independently.

Based on the observation data, it was found that the teacher's performance in the personality aspect reached $83.61 \%$ with the classification $\mathrm{B}$ in the good category. Most of the indicators of personality aspects have been fulfilled properly. Teachers at SD Negeri 35 OKU are senior teachers who have a working period of 15-25 years. So in the aspect of their personality they have been formed from experience and are more competent.

3. Social Aspects

Social competence is the ability of educators as part of society. How to socialize with the environment around the school will affect teacher performance. The instrument used to measure the social aspects of the teacher is

Table 8. Teacher Social Instruments

\begin{tabular}{|l|l|l|l|l|}
\hline \multirow{2}{*}{ Indicator } & \multicolumn{3}{|c|}{ Score } \\
\cline { 2 - 5 } & 1 & 2 & 3 & 4 \\
\hline a. Communicating orally, in & & & & \\
& writing and gestures & & & \\
\hline b. Using technology & & & & \\
\hline c. Associating actively & & & & \\
\hline d. Courtesy according to norms & & & & \\
\hline e. Principles of brotherhood and & & & & \\
togetherness & & & & \\
\hline f. Inclusive and non- & & & & \\
& discriminatory & & & \\
\hline
\end{tabular}

Guidelines for filling (4) head the school implements all the criteria in the indicators: very good (3) the principal implements most of the criteria: good (2) the principal implements a small number of criteria: sufficient / sometimes (1) the principal does not fulfill all the criteria: insufficient / no

Data- The social aspect data that researchers have collected through the guidelines for filling out teacher performance observations is (a) the teacher can communicate verbally, in writing and / or gestures politely (b) The teacher uses communication and information technology functionally (c) the teacher interacts actively in communication (d) get along politely with the surrounding community by observing the prevailing norms (e) apply the principle of true brotherhood and the spirit of togetherness.

From observations in the field of data collection on the social aspects of teacher performance with the achievement of criteria of $81.55 \%$, classified B with good category. SD Negeri $35 \mathrm{OKU}$ is located in the border area of the OKU and East OKU local governments, with heterogeneous environmental conditions and different cultures 
requiring a fairly high social attitude. Point $b$ is one of the deficiencies of teacher competence, namely the functional use of communication and information technology. Adjustment of the learning system during the pandemic, which requires the use of communication technology, is constrained by human resources who are still technologically illiterate. This is a concern for school principals, education offices and related institutions in the context of improving human resources. To solve this problem, learning at SD Negeri 35 OKU implements online and offline combination learning.

4. Professional Aspects

Professional competence uses instruments. To determine the professional aspects of teachers using the following instruments

Table 9. Teacher Professional Instruments

\begin{tabular}{|l|l|l|l|l|}
\hline \multicolumn{2}{|c|}{ Indicator } & \multicolumn{3}{|c|}{ Score } \\
\cline { 2 - 5 } & 1 & 2 & 3 & 4 \\
\hline a. Use of methods The & & & & \\
\hline b. $\begin{array}{l}\text { suitability of material to the } \\
\text { curriculum }\end{array}$ & & & & \\
\hline c. Relationship of lesson concepts & & & & \\
\hline d. Application of scientific & & & & \\
\hline $\begin{array}{l}\text { concepts } \\
\text { Heterogeneous and not } \\
\text { idealistic }\end{array}$ & & & & \\
\hline
\end{tabular}

Guidelines for filling (4) the principal implements all the criteria in indicator: very good (3) the principal implements most of the criteria: good (2) the principal implements a small number of criteria: sufficient / sometimes (1) the principal does not fulfill all the criteria: lacking / not

In the professional aspect there are indicators (a ) the concepts, structures and methods of science / technology / art that cover / are coherent with the material (b) the teaching materials in the school curriculum (c) the relationship of concepts between related subjects (d) apply scientific concepts in everyday life ( e) professional competence in a global context while preserving national values and culture.

From the data that has been collected, the professional aspect of the teacher has achieved the criteria of $74.4 \%$, which is categorized as sufficient. Thematic learning systems in elementary schools require teachers to be more professional in linking conceptual relationships with subjects. In order to support the assessment of primary school education, namely literacy, duration and character, it is very supportive in the effort to apply scientific concepts in everyday life (interview 26 October 2020)

Data from the competency aspects of teachers at SD Negeri 35 OK Pedagogical aspects of $83.5 \%$, the personality aspect reached $84.84 \%$, the social aspect reached $81.5 \%$ and the professional $72.2 \%$ reached an average of $82.01 \%$. In accordance with the determination of the criteria for the achievement category of SD Negeri 35 OKU teachers classified B in good category.

Based on the results of the study, it can be argued that academic supervision carried out by the principal aims to foster teachers to be more skilled and competent in carrying out their duties. The implementation of continuous supervision, in accordance with the right techniques and procedures, is expected to improve teacher performance.

Academic supervision planning is prepared at the beginning of the new school year by involving teachers. The agreement between the principal and the teacher about the object to be supervised, makes programs, prepares instruments and compiles a schedule of supervision. Before the principal's academic supervision is carried out, a notification is held to the teachers, supervision is carried out twice in one semester. The techniques used are individual techniques in the form of class visits, class observations, private conversations, visiting class and self-assessing.

The supervision carried out by the principal goes according to the plan that has been made. Before supervising the principal, giving greetings, looking for an inconspicuous seat, recording every activity, paying attention to learning conditions and not reprimanding if the teacher has an error during learning. This aims to create a good teaching and learning situation in accordance with the principles of supervision, namely scientific, democratic, cooperative and constructive and creative. From the results of notes and checklists during the implementation of supervision, the principal as the supervisor evaluates by studying the data to determine which teachers are experiencing difficulties. In the evaluation activity the principal discussed the results of the supervision, prepared the evaluation, determined the place and time of the conversation. The principal is friendly, provides the opportunity to express opinions and provide easy and practical advice and provides motivation to correct weaknesses. Providing technical assistance and guidance to teachers in order to improve the quality of their performance in carrying out tasks is the goal of supervision.

From the results of the evaluation of academic supervision, the principal conducts supervision which is a series of academic supervision of the principal. The supervisory activity carried out is to make a teacher data document that has been supervised which contains the date of supervision, the purpose of the data obtained, discussion notes, problem solving, suggestions; provide feedback (feed back); determine learning monitoring; request learning progress 
reports; know the learning process and results; assess learning outcomes; know the quality standards of learning outcomes; develop the teaching profession, and carry out the procurement and utilization of learning resources. The duties of the principal in supervision are to provide guidance, assistance, supervision and assessment on issues related to technical implementation and development through program improvements to create teaching and learning situations. This data is supported by the results of interviews conducted by researchers with Mr. Adi Nopriansah, S.Pd, a teacher at SD Negeri 35 OKU, who stated that during this pandemic, teachers were required to have skills in making variations in learning methods. The principal has provided the widest possible opportunity for teachers to innovate in learning by completing suggestions and infrastructure to support learning both online and offline. (Interview results on October 26, 2020)

Likewise, Mrs. Endang Susilowati, S.Pd.SD stated in the interview that the difficulties experienced were in a different learning tool report format. Having discussions with the principal is very helpful in solving problems or difficulties.

The target of the school principal's academic supervision in the pedagogical aspect is good enough. Understanding educational insights and students; curriculum development; planning, implementing and utilizing learning technology; evaluation of learning outcomes and development of students. Various digital technology services that can be applied in learning during a pandemic, a teacher must be able to develop learning designs and encourage active participation of students and parents in learning.

Academic supervision of school principals can improve teacher performance in managing learning, especially during the pandemic with the application of technology as a learning medium (Interview results on October 26, 2020)

Teacher personality competencies must be role models for their students. From the observation data collection in the field of teachers of SD Negeri $35 \mathrm{OKU}$, it has fulfilled the indicators of personality aspects, namely the attitude of faith and piety; have a noble character; wise and prudent; democratic; independent; authoritative; stable; adult; honest; sportsmanship; become role models; evaluate their own performance and develop themselves independently and sustainably. In line with these data, the results of an interview with Mr. Bejo, S.Pd SD stated that a teacher must remain Ing Ngarso sung Tulodo, Ing Madya Mangun Karso, Tut Wuri Handayani which means that in front of setting an example, in the middle of building a will and behind giving support as a form from the personality of a teacher (Interview results on 26 2020) The transition from face-to-face learning to distance learning during a pandemic affects the social competence of teachers. The use of communication and information technology is very important and needs attention and the right solution in order to achieve learning objectives. In addition, a good teacher must be able to communicate verbally, in writing and / or signally, both with students, fellow educators, educational staff, leaders of educational units, parents of students and the community. Likewise, associating with the community must be polite and in accordance with applicable norms and can apply the principles of brotherhood and the spirit of togetherness. With academic supervision of the principal which aims to improve teacher performance during a pandemic through seminars, workshops, online webinars in order to recognize, study and apply communication technology to support the implementation of distance learning. (Interview results on October 26, 2020)

The target of professional aspect of the principal's academic supervision is to analyze the ability to master learning material extensively and deeply. The professional competence of SD Negeri 35 OKU teachers, which are dominated by professionally certified teachers, is able to apply concepts, structures and scientific methods that are coherent with the teaching material; teaching material is in the school curriculum; able to explain the conceptual relationship between related subjects; apply scientific concepts in everyday life; competence professionally in a global context while preserving national values and culture. The results of the interview with Mrs. Suparti, S.Pd.SD said that through academic supervision of the principal in improving teacher performance, for example in studying the conceptual relationship between related subjects such as a network of themes that must be prepared before learning. Achieving basic education goals is more emphasized on the psychomotor or skill aspects. This condition is very necessary in order to achieve assessment of primary school education, namely literacy, numeracy and character surveys as a support in the effort to apply scientific concepts in everyday life (Interview results 26 October 2020).

Table 10. Results of supervision observation

\begin{tabular}{|l|}
\hline Aspects of Observation Results Category \\
\hline Planning83.3\% Good \\
Implementation $85.7 \%$ Good \\
Evaluation $82.2 \%$ Good \\
Supervision $82.2 \%$ Good \\
Average $83.35 \%$ Good \\
\hline
\end{tabular}

Based on Analysis of the data above, it can be concluded that the principal's academic supervision which includes aspects of planning, implementation, 
evaluation and supervision carried out by the principal of SD Negeri 35 OKU is included in the B category of good category with achievement criteria of $83.35 \%$.

Table 11. Observation Results of Teacher Performance

\begin{tabular}{|l|}
\hline Aspects of Observation Results in Categories \\
\hline Pedagogic $83.5 \%$ Good \\
Personality $84.84 \%$ Good \\
Social $81.5 \%$ Good \\
Professional $72.2 \%$ Fair \\
Average $82.01 \%$ Good \\
\hline
\end{tabular}

In addition to the principal academic supervision data there is Also teacher performance data covering pedagogic, personality, social and professional aspects of SD Negeri 35 OKU are classified as good category B with search criteria of $81.7 \%$.

To find out the role of principal supervision in improving teacher performance, researchers compared the results of the analysis of the implementation of principal supervision with the results of the analysis of teacher performance. From the analysis, it was found that teacher performance was relatively balanced with the results of the implementation of school principal supervision. The higher (better) the implementation of the principal's academic supervision, the higher (better) the teacher's performance will be.

The purpose of academic supervision is to help develop professional abilities, monitor the process of teaching and learning activities, encourage teachers to apply and develop their own abilities and encourage teachers to have serious attention to their duties and responsibilities.

\section{CONCLUSION}

Based on the data that has been collected and analyzed in the study, it can be concluded that the results of the principal's academic supervision are able to improve teacher performance in pedagogic, personality, social and professional aspects. This condition indicates that the role of principal academic supervision has a very important role in improving teacher performance.

Based on the process of collecting and analyzing data and conclusions, the implication of this study is that if the principal's academic supervision is carried out properly and continuously by paying attention to the objectives, functions, principles and proper techniques, the principal's academic supervision can improve teacher performance. Furthermore, if the teacher's performance reaches a better level, it will be able to affect the quality of education so that educational goals will be achieved.

This study provides suggestions for the implementation of the principal's academic supervision should be improved and carried out routinely so that every teacher can receive supervision so that they can identify deficiencies and receive suggestions for improving learning activities. supervisory evaluation should use assessments carried out objectively, both for teaching ability and discipline. The importance of academic supervision for teachers and schools needs to be socialized by the principal with the aim of raising awareness of each teacher and providing encouragement and motivation to improve teacher performance. Teachers must have the motivation and motivation to always improve the quality of learning and have readiness and innovation in the implementation of learning. This research can be used as a reference and reference in examining the implications of the role of principal academic supervision in improving teacher performance. There needs to be a deeper study of aspects, indicators and sub indicators in the preparation of research guidelines.

\section{ACKNOWLEDGMENT}

With the publication of this journal, the researchers expressed their gratitude to the honorable Mr. Chancellor of the PGRI Palembang University, Mr. Plt. Director of the Graduate Program at the PGRI University of Palembang, Mr. Plt. Assistant Director of the PGRI Palembang University Postgraduate Program, Head of the Education Management Study Program of the PGRI Palembang University / Supervisor I and Supervisor II, the head of SD Negeri 35 OKU along with the board of teachers and all friends who helped the completion of this research.

\section{REFERENCES}

[1] Ridho, S. (2020). Pendidikan Daring di Masa Covid 19. Kompas.com di https://www.kompas.com/edu/read/2020/08/12/ 112834471/pendidikan-daring-di-masa-covid19

[2] Himawan, F. U. (2021). Pendidikan Masa Pandemi. BBC News Indonesia di https://www.bbc.com/indonesia/indonesia55525851

[3] Ilyasa, F., Rahmayanti, H., Muzani, M., Ichsan, I. Z., \& Suhono, S. (2020). Environmental education for prevent disaster: a survey of students knowledge in beginning new normal of COVID-19. International Journal on Advanced Science, Education, and Religion, 3(2), 1-8. 
[4] Rahimah, R., Juriah, N., Karimah, N., Hilmatunnisa, H., \& Sandra, T. (2020). The Problems and Solutions for Learning Activities during Covid-19 Pandemic Disruption in Hidayatul Insan Pondok School. Bulletin of Community Engagement, 1(1), 13-20.

[5] Suryosubroto. (2010). Manajemen Pendidikan di Sekolah. Jakarta: PT Rineka Cipta

[6] Daryanto., \& Tutik, R. (2015). Supervisi Pembelajaran Malang: Gava Media

[7] Rodliyah, S. T. (2014). Supervisi Pendidikan dan Pembelajaran. Jember: STAIN Jember Press

[8] Said, A., \& Muslimah, M. (2021). Evaluation of Learning Outcomes of Moral Faith Subjects during Covid-19 Pandemic at MIN East Kotawaringin. Bulletin of Science Education, 1(1), 7-15.

[9] Djafri, N. (2016). Manajemen Kepala Sekolah. Gorontalo: Budi Utama

[10] Andang. (2014). Manajemen Kepemimpinan Kepala Sekolah. Jogjakarta:Ar-Ruzz Media

[11] Fitria, H., Kristiawan, M., \& Rahmat, N. (2019). Upaya Peningkatan Kompetensi Guru Melalui Pelatihan Penelitian Tindakan Kelas. Abdimas Unwahas

[12] Sohiron. (2015). Administrasi dan Supervisi Pendidikan. Pekanbaru:Kreasi Edukasi

[13] Hendarman., \& Rohanim. (2018). Kepala Sekolah Sebaga Manajer Bandung: Remaja Rosdakarya

[14] Fitria, H. (2018). The Influence Of Organizational Culture And Trust Thtough The Teacher Performance In The Private Secondary School In Palembang. International Journal of Scientific \& Technology Research.

[15] Fitira, H., Mukhtar, M., \& Akbar, M. (2017). The Effect of Organizational StructureAnd Leadership Style on Teacher Performance In Private Secondary School. IJHCM (International Journal of Human Capital Management).

[16] Kristiawan, M. (2019). Supervisi Pendidikan. Bandung: Alfabeta

[17] Ahmad, S. (2016). Ketahanmalangan Kepemimpinan Kepala Sekolah. Palembang: Budi Utama

[18] Wiyani., \& Novan, A. (2015). Etika Profesi Keguruan. Yogyakarta: Gava Media

[19] [Cahyono, H., Suhono, S., \& Khumairo, A. (2018). Pendidikan Karakter Bagi Pelaku Pedofilia (sebuah Strategi dalam Mengatasi Amoral). JMKSP (Jurnal Manajemen, Kepemimpinan, dan Supervisi Pendidikan), 3(1), 1-19.
[20] Septiawati, L., \& Eftanastarini, I. (2020). Analisis Ketercapaian Standar Kompetensi Lulusan di MTS As Salam. Attractive: Innovative Education Journal, 2(1), 81-89.

[21] Mahmudah, M., Kapi, M. B., \& Muslimah, M. (2021). Parental Participation-Based Portfolio Assessment during Covid-19 Pandemic. Bulletin of Science Education, 1(1), 1-6

[22] Pianda, D. (2018). Kinerja Guru: Kompetensi Guru, motivasi Kerja dan Kepemimpinan Kepala Sekolah. Sukabumi: CV Jejak

[23] Jelantik, A. A. K. (2015). Menjadi Kepala Sekolah Yang Profesional. Yogyakarta: Budi Utama

[24] Sugiyono. (2019). Metode Penelitian Pendidikan. Badung: Alfabeta

[25] Nugrahani, F. (2010). Metode Penelitian Kualitatif. Surakarta: ISI Press

[26] Sukardi. (2018). Metodologi Penelitian Pendidikan. Yogyakarta:PT Bumi Aksara

[27] Siyoto, S., \& Ali, M. S. (2015). Dasar Metodologi Penelitian. Yogyakarta:Literasi Media Publishing

[28] Salim., \& Syahrum. (2012). Qualitative Research Methodology. Medan: Citapustaka Media

[29] Kementrian Pendidikan dan Kebudayaan. (2019). Supervisi dan Penilaian Kinerja Guru. Jakarta: Direktorat Jenderal Guru dan Tenaga Kependidikan

[30] Annur, S., \& Suhono, S. (2019). Implementasi manajemen pergruruan tinggi (studi kasus pada ptkis kopertais wilayah vii sumatera selatan). JMKSP (Jurnal Manajemen, Kepemimpinan, dan Supervisi Pendidikan), 4(1), 67-75. 